\title{
Näkökulmia oppimiseen työpaikoilla
}

\author{
PETRI LEMPINEN
}

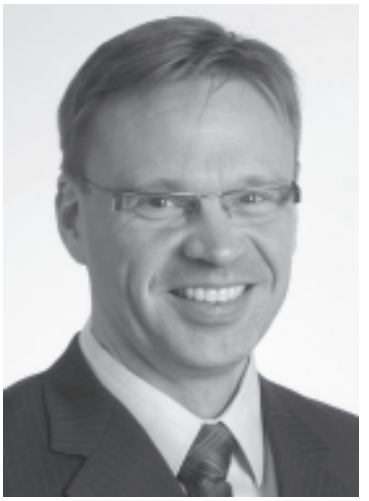

Elinkeinojen muuttuminen muuttaa ammatteja ja niiden vaatimuksia. Tämä on ollut todellisuutta läpi taloushistorian, mutta muutoksen kiihtyvät tahti haastaa nyt käsityksemme koulutuksesta ja oppimisen ympäristöistä. Viime vuosikymmenet Suomi on elänyt oppilaitoskeskeisen koulutusajattelun aikaa. Nyt muodollisen oppimisen ennustetaan siirtyvän enenevässä määrin työpaikalle. Miten tämä onnistuu?
S

uomen työ- ja elinkeinoelämä käy läpi vastaavaa rakennemuutosta kuin 1980-1990-luvuilla, jolloin mm. tekstiili-, vaatetus- ja kenkäteollisuus katosivat maastamme lähes kokonaan. Silloinen myllerrys koski myös palvelualoja hävittäen muiden muassa lähes puolet pankkien työpaikoista. Tuolloin työpaikkojen kato koski naisia. Nyt ovat metsä-, teknologia- ja metalliteollisuuden palveluksessa olevat miehet uhan alla.

Suomessa aikuiskoulutukseen osallistuvat naiset huomattavasti miehiä useammin. Teollisuuden rakennemuutos koettelee aikuiskoulutuksen kykyä vastata miesten tarpeisiin ja odotuksiin, jotka voivat olla erilaisia kuin naisilla. Myös miesten aikaisemmat koulukokemukset ja heidän käsityksensä muodollisesta koulutuksesta voivat poiketa naisten vastaavista. Aikuiskoulutuksessa on korostettu oman pedagogiikan tarvetta, koska aikuisten kokemusmaailma ja -tausta on erilainen kuin nuorilla vailla työkokemusta olevilla. Ehkä aikuispedagogiikassa on otettava nykyistä enemmän huokioon myös sukupuolinäkökulma?

Jos yhteiskunnallista muutosta tarkastelee elinkeinoelämää laajemmin, havaitsee Suomen olevan lähes samanlaisessa murroksessa kuin 1960-luvulla. Tuolloin maa kaupungistui ja siirtyi palkkatyöhön, kun suomalaiset siirtyivät sotien jälkeisiltä asutustiloilta aravalainoitettuihin elementtilähiöi- hin. Palvelut ohittivat maa- ja metsätalouden ja kohosivat teollisuuden rinnalle. Ylijäämäväestö muutti Ruotsiin antaen dopingruiskeen naapurimme talouselämälle. Suomeen jääneille luotiin koulutusjärjestelmä, asuntopolitiikka ja sosiaaliturva. Moderni Suomi näki päivänvalon.

2010-luvun koittaessa Suomi valmistautuu siirtymään palkkatyön yhteiskunnasta tulonsiirtojen yhteiskuntaan. Seuraavissa eduskuntavaaleissa keväällä 2011 työelämässä palkansaajana tai yrittäjänä olevat äänestäjät ovat vähemmistönä. Suurten ikäluokkien siirtyminen eläkkeelle näkyy politiikassa paitsi vanhusten elinolojen turvaamisen tarpeessa ja julkisen talouden ongelmien kasvussa, myös eläkeikäisten äänestäjien lukumäärässä. Miten elinikäinen oppiminen muuttuu yhteiskunnassa, jota entistä enemmän kansoittavat eläkeläiset? Koulutus voi tehdä paljon vanhenevan väestön toimintakyvyn ja vireyden eteen. Vapaa sivistystyö voi olla mitä mainioin tapa edistää kansanterveyttä.

Aivan kuten 1960-luvulla tarvitaan nyt yhteiskunnan voimakasta uudistumista, jotta me Suomessa kykenemme huolehtimaan itsestämme. Kyse ei ole vain vanhusten hoidosta vaan myös työikäisen väestön motivaatiosta ja jaksamisesta. Elinikäinen oppiminen tai suppeammin katsottuna koulutus- ja työvoimapolitiikka ovat keskeisiä keinoja 
yksittäisten suomalaisten ja koko Suomen tulevaisuuden rakentamisessa. Uusi aika vaatii kuitenkin uudenlaista sisältöä näille politiikan lohkoille.

\section{Miten korkealle voi väestön koulutustasoa nostaa?}

Suomalaisen koulutus- ja talouspolitiikan johtoajatus on perustunut koulutustason jatkuvaan nostamiseen 1960-luvulta lähtien. Peruskoulu, valtakunnallinen yliopistolaitos, keskiasteen kouluuudistus ja ammattikorkeakoulut ovat nykyisen elintasomme ja menestyksemme avaintekijöitä. Suomessa vannotaan yhä osaamiseen ja innovaatioihin. Ovatko keinot niiden saavuttamiseen vuonna 2015 samat kuin 1960- tai edes 1990-luvulla?

Vuosikymmenten työ opiskelumahdollisuuksien luomiseksi näkyy nyt työikäisten koulutustasossa. Tilastokeskuksen työolotutkimusten mukaan palkansaajien enemmistöllä eli 55 prosentilla oli vuonna 1977 vain perusasteen koulutus. Vuonna 1990 peruskoulutuksen varassa oli vielä kolmannes, mutta vuonna 2008 enää 14 prosenttia. Samana aikana korkea-asteen koulutuksen, sisältäen aiemmat opistot, suorittaneiden osuus on nelinkertaistunut 41 prosenttiin.

Kun yhä suurempi osa työikäisistä on suorittanut jonkinlaisen ammatillisen koulutuksen ja jopa tutkinnon, voisi kuvitella aikuisten koulutustarpeiden muuttuvan. Perustutkintojen sijasta tarvitaan entistä enemmän täydennyskoulutusta, vaikka ammatillinen tai korkea-asteen perustutkinto voi jatkossakin olla tarpeen ammattia vaihdettaessa. Tähän ajatteluun perustuu jo mainittu ajatus oppimisen siirtymisestä työpaikoille, mikä korostui myös ammatillisesti suuntautuneen aikuiskoulutuksen kokonaisuudistuksen (AKKU) valmistelussa vuosina 2007-2009.

Aiempaa parempi peruskoulutus yhdistettynä työkokemukseen tarkoittaa, että pitkäaikaisen koulutuksen sijaan tarvitaan yhä enemmän täydennyskoulutusta. Muuttuvassa ja sirpaloituvassa työelämässä oleville tarvitaan yksilöllisiä ja joustavia koulutusratkaisuja. Osaamisen tunnustaminen ja opintojen henkilökohtaistaminen ovat tarpeen johtaapa koulutus perustutkintoon tai osaamisen vahvistamiseen. Tämä koskee ammatillisen tai työvoimapoliittisen aikuiskoulutuksen lisäksi korkeakoulujen tarjontaa. Instituutioihin ja tutkintoihin keskittynyt koulutuspolitiikka on käännettävä samaan suuntaan yhteiskunnan kehityksen kanssa.

\section{Insinöörikoulutuksen painopiste täydennyskoulutukseen}

Aikuiskoulutuksen mahdollisuuksia koulutuspolitiikan reivaamisessa ei ole hyödynnetty riittävästi. Esimerkiksi kelpaa tekniikan korkeakoulutus, jonka koulutustehtäviä voisi määrittää reippaasti uudella tavalla. Suomalaisen insinöörikoulutuksen ongelmana pidetään yleisesti liian laajaa ja hajanaista koulutustarjontaa. Aloituspaikkoja on enemmän kuin kelpoisia hakijoita, joten opintojen keskeyttäminen on liian korkeaa. Puolet aloittaneista ei saa tutkintoa valmiiksi.

Insinöörikoulutuksen kohderyhmäksi voisi ottaa työikäiset, joilla on jo tekniikan alan peruskoulutus. Tuolloin tavoitteena olisi koulutustason nostaminen ja osaamisen parantaminen samanaikaisesti. Ajan tasaiselle ja korkeammalle tekniikan osaamiselle on varmasti kysyntää, jos Suomessa on tulevaisuudessa teollista toimintaa ja rakentamista.

Kansallisen innovaatiojärjestelmän arviointiraportti syksyltä 2009 osoittaa, että ainakin kolmanneksen kaikista tutkimus- ja kehitystyöhön käytetyistä tunneista tekevät alemman korkeakoulututkinnon tai vastaavan suorittaneet. Erityisesti yrityksissä vastuu tutkimus- ja kehitystoiminnasta (t\&k) on insinööreillä. He tekevät yritysten tuotekehitykseen käytetyistä tunneista 53 prosenttia. Julkisen sektorin, sektoritutkimuslaitokset mukaan lukien, t \& k -resurssista kolmannes ja korkeakouluissa neljännes on alemman korkeakoulututkinnon suorittaneiden vastuulla.

Jos Suomi haluaa panostaa tutkimus- ja kehitystyöhön, on sijoitettava näiden henkilöstöryhmien osaamiseen. Tohtorikoulutus, mihin yhdistyy korkeakouluissa tehtävä perus- tai soveltava tutkimus, on tärkeää, mutta se on liian suppea tapa vastata $\mathrm{t} \& \mathrm{k}$-henkilöstön osaamistarpeisiin. Teollisuuden toimintaedellytyksiä voidaan parantaa kehittämällä myös nykyisen $\mathrm{t} \& \mathrm{k}$-henkilöstön osaamista, ei vain uutta henkilöstöä kouluttamalla.

Tutkimus- ja kehitystyötä jo tekevien lisäksi kohderyhmänä olisivat teollisuuden rakennemuutoksissa työnsä ja ammattinsa menettävät. Vanhoista - koulutukselta ei iältään - teknikoista voisi kouluttaa insinöörejä. Vanhat insinöörit voisivat päivittää tutkintonsa amk-tasolle tai suorittaa ylemmän korkeakoulututkinnon. Osaamisen tunnustamisen ja henkilökohtaistamisen periaatteiden mukaisesti uudelle tekniikan alalle opiskeleminen 
olisi mahdollista tehdä alle kahdessakin vuodessa, jos tiedon siirtämistä oppilaitoksissa täydennetään työpaikalla tapahtuvalla oppimisella. Vastaavasti tekniikan osaamista voidaan täydentää liiketoimintaosaamisella tai päinvastoin. Työpaikkansa menettävän paperitehtaan vuoromestarin ainoana vaihtoehtona ei tarvitse olla hoitoalan. Hänen uusi ammattinsa voisi ponnistaa lähempääkin, nykyisestä tekniikan osaamisesta.

Ammattikorkeakouluilla on tähän jo nyt useita työkaluja alkaen ylemmästä amk-tutkinnosta ja päättyen erikoistumisopintoihin. Yhdessä yliopistojen kanssa ammattikorkeakoulut voisivat kehittää käytännöllisiä DI-ohjelmia työssä olevien tarpeisiin.

Tuhannet korkeakoulutetut ovat jo suorittaneet johtamisen erikoisammattitutkintoja oppisopimuksen lisäkoulutuksena. Yliopistot ja ammattikorkeakoulut harjoittelevat oppisopimustyyppistä täydennyskoulutusta. Korkeakoulutettujen alan vaihtaminen ja koulutustason kohottaminen voisi myös tapahtua yhdistämällä työssä oppiminen teoriakoulutukseen. Tämä edellyttää kuitenkin uudenlaista ajattelua koulutuksen järjestämisessä. Ensisijaisena lähtökohtana eivät voi olla korkeakoulun tai muun oppilaitoksen opetussuunnitelmat vaan yksilöiden ja ammattien tarpeet.

\section{Osaamisen tunnustaminen $=$ hops}

Työelämässä kehityskeskustelut ovat keskeisiä työkaluja osaamisen nykytilan arvioinnissa ja tulevaisuuden tavoitetason asettamisessa. Oppilaitoksissa ja korkeakouluissa kehityskeskustelun sijasta tehdään henkilökohtaisia opintosuunnitelmia tai vastaavia. Osaamisen tunnistaminen ja ennen kaikkea tunnustaminen on etenkin korkeakouluissa hankalaa, koska muodollisen koulutuksen kokonaisuuksia ei ole rakennettu osaamisen ja oppimistulosten näkökulmasta. Näin muun kuin koulutuksen tuottaman osaamisen tunnistaminen oppilaitoksissa on vaikeampaa kuin kehityskeskustelussa. Osaamisen tunnustamisen ongelmat kertovat myös korkeakouluväen epäilyistä oppilaitoksen ulkopuolella opitun hyödyllisyydestä opintojen suhteen.

Suomalaisiin korkeakouluihin on kehitetty periaatteet aiemmin hankitun osaamisen tunnustamisesta. Itse termikin tekee rajan oppimiseen oppilaitoksen ulko- ja sisäpuolella. Osaamisen tunnustamisen pitäisi olla osa henkilökohtaisen opintosuunnitelman tai vastaavan tekemistä. Muodol- lisen koulutuksen yhteydessä osaamista voi tunnistaa ja tunnustaa vain suhteessa suoritettavan opintokokonaisuuden vaatimuksiin. Osaamisen tunnustamisen on oltava aina kriteeriperusteista. Tämä periaate on käytössä ammatillisessa koulutuksessa, missä opiskelijat näyttävät osaamistaan käytännön työtilanteissa. Tämä on mahdollista tuoda myös tietotyöhön valmistaviin korkeakoulutuksiin, jos tutkinnot ja opetussuunnitelmat kuvataan osaamisen perusteella.

Internetillä ja muulla tieto- ja viestintätekniikalla on ollut suuri vaikutus oppimisen muutoksiin. Ne ovat tuoneet tiedon yhä useamman ulottuville. Myös Internet on hämärtänyt rajaa koulutuksen ja arjessa oppimisen välillä. Uuden tekniikan kääntöpuolena on informaation tulva, missä hyödyllinen ja hyödytön tieto puuroutuvat. Sähköposti on paitsi tehokas viestin, myös työn keskeytysten ja häiriöiden lähde. Sähköpostin määrä kasvaa Euroopassa noin 40 prosenttia vuodessa. Tietotyöläisen keskeytymätön työaika on noin kolme minuuttia. Taukoamaton viestintä lisää kuormitusta ja aiheuttaa virheitä, jotka johtavat keskittymisen puutteesta.

Tämä muuttaa perinteisiä oppilaitoskeskeisiä oppimisympäristöjä ja samalla opettajan työtä. Diginatiivit ovat kuin kotonaan virtuaalimaailmassa - ainakin jos heitä vertaa varttuneempaan väkeen. Tottumus netin käyttöön ei kuitenkaan todista kyvystä hyödyntää sen mahdollisuuksia opinnoissa tai työelämässä. Uusien välineiden ja sisältöjen hyödyntäminen edellyttää koulutusta. Sitä tarvitsevat niin opettajat kuin elinikäiset oppijat.

Tietojen ja taitojen siirtämisen lisäksi opettajan tehtäväksi tulee nuorten ja aikuisten oppijoiden uudenlaisen potentiaalin saaminen näkyväksi. Tähän liittyvät myös osaamisen tunnustamisen ja tunnistamisen tehtävät, jotka muuttavat opettajuutta. Opettajien täydennys- ja peruskoulutuksen on muututtava vastaamaan opettajan työn uudistuvaa todellisuutta.

\section{Ehtiikö työpaikalla oppia?}

Rakennemuutoksen ohessa työpaikkoja leimaa lisääntyvä kiire. Tuottavuutta on haettu julkisella ja yksityisellä sektorilla vähentämällä henkilöstöä. Tämä tuskin muuttuu, jos suurten ikäluokkien eläkkeelle siirtymisestä seuraa ennustettu pula osaajista. Henkilöstön mitoituksella on vaikutus koulutukseen osallistumiseen. STTK:n toimihenkilö- 
barometri on koko 2000-luvun osoittanut, että kiire ja sijaisten puute ovat syitä, joiden vuoksi koulutukseen ei osallistuta.

Työolotutkimusten mukaan noin 55 prosenttia työvoimasta osallistuu koulutukseen. Lähes samaan on päädytty toimihenkilöbarometreissä. SAK:n jäsenkyselyt puolestaan kertovat, että työntekijäammateissa vain reilu neljännes osallistuu työnantajan järjestämään henkilöstökoulutukseen. Henkilöstökoulutus kasaantuu samalla tavalla kuin muuhunkin aikuiskoulutukseen osallistuminen. Mitä parempi on pohjakoulutus, sitä todennäköisemmin osallistutaan tai päästään koulutukseen.

Oppiminen, opiskeleminen tai kouluttautuminen muuttaa muotoaan siinä kuin osaamistarpeetkin. Elinikäinen oppiminen on enemmän kuin koulutus tai opiskeleminen. Kyse on entistä useammin oppimisesta työssä ja muissa arjen tilanteissa. Tuolloin ammattitaidon parantuminen tai oppiminen tapahtuu työn yhteydessä, uusia laitteita tai menetelmiä opeteltaessa tai kehitettäessä. Työssä kehittyminen on usein käytännön tilanteiden ja pulmien ratkaisemista.

Tämänkaltainen oppiminen tai ammatissa kehittyminen ei tule näkyviin tilastoissa tai kyselyissä, joissa päivinä mitataan osallistumista työnantajan maksamaan koulutukseen. Tämä on tullut esiin mm. Elinkeinoelämän Keskusliiton EK:n vuonna 2009 julkaisemasta selvityksessä Henkilöstön kehittämisestä yrityksissä.

Sama pulma on koulutuspolitiikassa. Oppiminen ja opiskeleminen on rajattu tutkintojen ja niihin valmistavien koulutusten muotteihin, joille on tarjolla erilaista julkista rahoitusta. Näin aikuiskoulutuksen malli on liian usein samantapainen kuin nuorten koulutuksessa. 1990-luvulla aikuisten tarpeisiin luotiin osaamisen tunnustamiseen näyttötutkinnot. Niistä on kuitenkin muodostunut koulutusväylä, kun valmistava koulutus vaikuttaa tutkintojen suorittamista tärkeämmältä.

Kun oppiminen siirtyy työpaikoille, on haasteena ajan löytäminen. Työpaikalla on oltava riittävästi henkilöstöä, että he voivat jakaa tietoa ja luoda uutta käytännön arjessa. Oppiminen työssä on aktiivista osallistumista, ei vain tiedon siirtämistä tai taitoihin harjaantumista.

Nykyisin työelämä korostaa yksilöitä, mikä ei kannusta yhdessä oppimiseen tai jakamiseen. Useimmat organisaatiot toimivat tiimeinä, mutta työntekijöinä ja esimiehinä meitä mitataan yksilöinä. Oppiminen edellyttää usein epäonnistumista. Onko tämä sallittua jatkuvan tuloksen tekemisen ilmapiirissä. Kuka haluaa jakaa epäonnistumisen, kun se vaikuttaa seuraavaan henkilökohtaiseen palkanlisään? Tuottavuuden kehittäminen riippuu osaamisesta ja tuloksen tekemisestä. Nämä voivat olla työn arjessa joskus ristiriidassa.

Esimiehellä ja ylipäänsä johtamisella on suuri vastuu oppimisesta työyhteisössä. Kaikki eivät ole hyvin koulutettuja tietotekniikan ja oppimisen ammattilaisia. Hyvin moni meistä tarvitsee ohjausta, tutorointia ja tukea - jos ei mukana vetämistä, niin vierellä kulkemista.

Hyvällä työpaikalla on oppimista edistävä ilmapiiri, johon sisältyy esimiehen ja kollegoiden kannustusta ja luottamus. Jotta oppiminen on mahdollista, se on vietävä osaksi työpaikan arkea ja työtehtävien kehittämistä. Työssä on oltava aikaa oppia. Oppimisen esteitä ovat mm. kiire, pätkätyöläisyys, henkilöstön vähäisyys ja työtehtävien siirtyminen projekteihin. Esimerkiksi yksin työskenteleminen voi johtaa tilanteisiin, joissa ei tapahdu tiedonsiirtoa muille työntekijöille.

\section{Kokonaisuudistus jäi vaiheeseen}

Keväällä 2007 hallitusohjelmassa sovittiin ammatillisesti suuntautuneen aikuiskoulutuksen kokonaisuudistus. Tarkoitus oli laittaa aikuiskoulutuksen hallinto, tarjonta ja rahoitus kuntoon. Toisin kuitenkin kävi. AKKU-työltä puuttui selvä poliittinen tavoite tai päämäärä, jolloin se jäi kellumaan uuden työ- ja elinkeinoministeriön perustamisen sekä aluehallinto- ja yliopistouudistusten väliin. Uudistusta valmistellut johtoryhmä teki lukuisia ehdotuksia, joista ei muodostunut selkeää kokonaisuutta. Kansantalouden romahdus valmistelun aikana sekoitti osaltaan pakkaa. Pitkän tähtäimen kehittämisen sijasta huomiota oli pakko suunnata työttömyyden vaurioiden minimoimiseen.

AKKU ei epäonnistunut, mutta kokonaisuudistukseksi sitä ei voi sanoa. Konkreettista etenemistä tapahtui lähinnä aikuisopiskelijoiden etuuksien osalta. Opintovapaan aikaisen aikuiskoulutustuen taso nostetaan kesällä 2010 samalle tasolle kuin työttömyysturva. Tämä tarkoittaa lähes 30 prosentin tasokorotusta. Työttömät ovat jo vuoden 2010 alusta voineet opiskella samansuuruisella tuella omaehtoisessa ja työvoimakoulutuksessa. Tämä korostaa työttömäksi jäävän omaa aktiivisuutta koulutusvalintojen tekemisessä. Kysymys koulutuspaikkojen riittävyydestä ja koulutukseen pääsystä jäi auki. Kun ansiosidonnaista työttömyysturvaa - myös opintoihin - saa enintään 500 päi- 
vää, olisi koulutukseen päästävä pikaisesti. Kaksi kertaa vuodessa järjestettävä yhteishaku, jonka perusteella voi päästä koulutukseen, joka alkaa kuukausien päästä, ei lohduta työnsä menettänyttä.

Myös korkeakoulujen rooli aikuiskoulutuksessa määritettiin aiempaa selvemmin. Yliopistolain uudistuksessa elinikäisen oppimisen edistäminen määritettiin yliopistojen tehtäväksi. Sama lain määräys ulotettiin myös ammattikorkeakouluihin.

Korkeakoulutettujen tarpeisiin kehitettiin uusi osaamiskokonaisuus, erityispätevyys, johon voi valmentautua oppisopimustyyppisellä koulutuksella. Yritys on ollut hyvä ja uuden koulutusmuodon käynnistämiseen on löytynyt rahoitusta. Korkeakoulut saivat siis uuden tuotteen. Vähemmälle jäi sen pohtiminen, miten olemassa olevaa julkista resurssia pitäisi käyttää tehokkaammin hyväksi. Korkeakoulujen rakenteellinen kehittäminen ei yhdistynyt korkeakoulujen aikuiskoulutustehtävän pohdiskeluun.

Maahanmuuttajien koulutuksen osalta AKKUtyössä koottiin kasaan noin 50 toimenpide-ehdo- tusta. Nämä ovat rahapulassa jääneet käytännössä toteuttamatta. Maahanmuuttaja-asioiden hallinnon siirtäminen sisäministeriöön ei helpottanut valmistelu tai toimeenpanoa, koska resurssit ovat opetus- ja työvoimahallinnon käsissä.

Perusongelmana oli jääminen nykyisiin rakenteisiin ilman niiden kyseenalaistamista. Koska aiemmin on ollut aikuiskoulutusta opetusministeriön ja työministeriön hallinnonaloilla, on niin oltava jatkossakin. Vaihtoehtona olisi ollut uuden toimintamallin rakentaminen, mikä olisi koonnut yhteen nykyisiä koulutusmuotoja. Työelämään ja oppijoille tämä olisi voinut tuoda selkeyttä. Integraation sijaan ammatillisen ja työvoimapoliittisen aikuiskoulutuksen raja-aita säilyi vankkana. Koska OPM:1lä on oppisopimuskoulutuksen, keksittiin työvoimakoulutukseen myös TOPPIS-koulutus, mikä tapahtuu työpaikoilla. Uusille ELY-virastoille ei uskallettu miettiä laajempaa roolia koulutuksen suuntaamisessa tai rahoittamisessa maan eri alueilla. Ohjauspalveluiden järjestämisestä saatiin kasaan vain kolme yleistä toivetta. Näihin haasteisiin on tartuttava seuraavalla hallituskaudella. 